\title{
SOCIOECONOMIC VERSUS NATURAL SYSTEM IN A DYNAMIC LAKE LANDSCAPE: A CASE STUDY OF JEZIORAK LAKE IN POLAND
}

\author{
ADAM J. CZARNECKI \& ANNA LEWANDOWSKA-CZARNECKA \\ Institute of Ecology and Environment Protection, Nicholas Copernicus University in Torun, Poland.
}

\begin{abstract}
In this paper changes in the landscape were analysed in the direct drainage area of Jeziorak Lake. They can be traced back to stages in the development of the man-environment system, that is, drawing from the ecosystem, the intensification of farming and trade and the development of tourism and building. The landscape, on which man drew for ecosystem products for his survival, was highly natural and variety was added by paying attention to fixed features of the land. The participation of country areas surrounding the lake changed its type of landscape to a natural-agricultural character. Buildings, meadows and fields were well matched with the natural flora. Structure of ecosystem is preserved but waters were polluted with flows from farmland. Recently tourism and building are changing the landscape in many parts disadvantageously for the landscape and ecosystem. The interference in the flora of the littoral is reducing the ability of the ecosystem to self-cleanse water and stabilize soil directly in the drainage area.

Keywords: Agriculture, ecosystem products and services, landscape, sustainable development, tourism residential buildings.
\end{abstract}

\section{INTRODUCTION}

Lakes in Poland are very attractive for tourism. The small area, as well as the water volume of often shallow lakes, means that they are sensitive to stress, while increasing exploitation means that maintaining a healthy lake becomes difficult and the health of the ecosystem and usefulness in the future become uncertain. Shallow lakes with an unstable dynamic change over time in response to internal and external inputs and processes. A system change that can lead to problems is the process of eutrophication, which means the enrichment of the system with inorganic nutrients, either in soluble form or associated with organic matter or silt. Solutions applied to prevent degradation rather represent a compromise, which can result in weak effects. The way to achieve a higher ecosystem quality and yield of a higher average social utility could be integrative solutions. Ecosystem management issues must include the recognition of ecological functions and the structures of administrative and ownership boundaries. Integrated, holistic knowledge is necessary for management planning. It can contribute by formulating an important requirement for achieving socially fair sustainable use of ecosystems. Integrative solutions for the shared use of ecosystems require insight into ecosystem services which must withstand the stress of increasingly different forms of use. It is known that utilities depending on ecosystem quality and optimal shared use depend on activities that are detrimental to ecosystem quality. Using lakes and putting pressure on the ecosystem started from the deep past when people used part of the productivity and other natural resources from lakes and land within the catchments area for fulfilling different needs. This included giving larger yields of productivity because of the increasing demand for food and wood and land transformation through controlling land humidity and by connecting natural rivers and lakes into long water routes. Development of these activities caused water pollution by introducing industrial waste, municipal sewage and different chemicals to the lakes. To that can be added nowadays increasing demand for spatial resources, with encroaching of the building environment and places for recreation [1]. Growing risks to the environment can become apparent [2]. Stress caused by previous forms of ecosystem utilities 
and pressure from established forms of management are abating but new ones caused by tourism and recreation in Poland are not recognized and counteracted. Based on the example of Jeziorak Lake analysis provides insight into the relation between social multi-stress and ecosystem changes in view of the ability to provide ecosystem services for social use.

\section{AREA}

Jeziorak Lake is one of the biggest lakes in Poland and is very popular among tourists [3]. It enables safe sailing and offers a diversified shore line adapted to prolonged contact with the forest. Yachtsmen can connect with the sea, through the Elbląg channel. Surroundings of lake are protected as landscape park (Table 1). It is situated in the drainage area of the river Ilawka, which is a right-bank inflow to the upper Drwęca. The total drainage area of the lake is $314.9 \mathrm{~km}^{2}$ of which $165 \mathrm{~km}^{2}$ is in the direct drainage area of the lake. This area embraces fragments of three units differing by geology and relief. There is an undulating moraine area with abundant hollows and with gutters and hills in the north-eastern part of Jeziorak. The remaining centre and western part of the Jeziorak drainage area is sandy uplifted by sands and aqueous-glacial gravels.

The drainage area of sandy soils is covered with forests and bogs in which pine and spruce predominate. On the bottom moraine is a beech forest. Especially the northern part is used for farming where crop fields are dominant. Meadows and bogs contribute a little to land cover. The majority of the shoreline is clear bank side. Rippling is diversified to two main biotypes lentic and lenitic. On wind shores, there are few deposits and reeds dominate. From the side of forest, Potamogeton appears. The littoral lenitic, where there are many deposits at the bottom, appears Typha.

\section{BACKGROUND AND SCOPE OF RESEARCH}

Jeziorak Lake is situated near populated area and farming in the past brought it to a state of eutrophication resulting from the use of fertilizers on the surrounding land and an increased inflow of waste water from human settlements and industries. Despite large investments to control the process, as other many shallow lakes, in contrast to some deeper lakes, little improvement has yet shown. It is a consequence of the fact that shallow lakes tend to remain in a highly turbid eutrophic state even when the nutrient load is reduced to values well below those at which the collapse of the clear and vegetated state occurred. However, for the future, a positive feedback can be expected, which is probably achieved during the development of submerged vegetation. Now in very turbid water, light conditions are insufficient for vegetation development; but once vegetation is present, it can be expected that the water clears up and the improved light conditions allow the persistence of lush

Table 1: Some characteristics of Ilavian landscape park.

\begin{tabular}{lc}
\hline Characteristics & Landscape park \\
\hline Area [ha] & 43,083 \\
Catchment area [ha] & 31,495 \\
Lakes [ha] & 5006 \\
Forest [ha] & 8879 \\
Residents villages & 9410 \\
Ilawa town & 33,000 \\
Visitors/tourists in season about & 20,000 \\
\hline
\end{tabular}


vegetation [4,5]. It is important because light is likely to be a primary factor in limiting the colonization by submerged plants [6-9]. If so, water clarity tends to increase in the presence of plants [10-13]. Such a goal would be very important because a healthy ecosystem can maintain attractive resources for sustainable use, which is very important for the economy of the local society. Till now Jeziorak Lake has shown signs of being in an irreversible state; nevertheless, there are efforts to stop the impact of towns on the lake. This proves that there is a single dominant feedback mechanism or that the result of the total impact is not changing. So it is important to assess the total impact on the lake, including recreation and tourism development. If it rises, catastrophic change can be predicted as a response to gradual changes in structure, composition and biodiversity as consequences of unsustainable use. Continuing enrichment, making the lake more and more vulnerable to perturbations, will finally end with a transition with cyanobacteria occurrence, which has happened in some places, and cannot be neglected for socioeconomic reasons. Providing information from research would be useful for enhancing relations between users of ecosystem services and the ecosystem structure and function to ensure quality.

Therefore, stress increases resulting from human use not only by farming but also by tourism developing, a fact that has important implications for the interaction of ecosystems with socioeconomic systems, which expresses the concept of analysis (Fig. 1) referred by Hein et al. [14]. The question is how to use ecosystems to maximize benefits for different users. Analysis of the changing landscape can be an attempt to compare economic with environmental and cultural trademarks $[15,16]$ granting notable value individual components. Visual as well as functional guilds were subjected to such integrated analyses of the studied area (Fig. 1). In the analysed arrangement, priority was granted to ecosystem features $[2,17]$ because appropriate functioning of the ecosystem is able to meet the needs of people when it concerns aesthetic values of the landscape and also by fulfilling material needs with various ecosystem services and products. Landscapes are the ecosystem services not consumed; however, changes in the landscape released activities of great impact on the ecosystem. Although the function of the ecosystem is passive, it can also be active

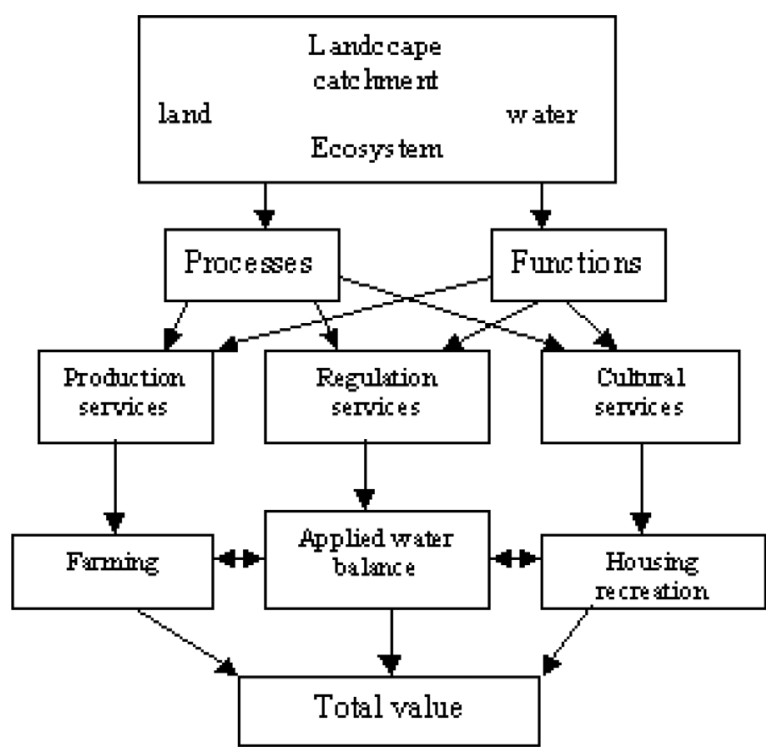

Figure 1: Concept of analysis. 
depending on structure and function. Considering tourism and the importance of the littoral zone, it is exactly the shoreline of lakes, which stabilizes the relation between the two main environments, water and land, as well as storing and transforming substances tending to flow to the lake ecosystem. Now it has become the place of human pressure. Shifts in the examined landscape started from the almost pristine stage when despite the impact of man, it was possible to sustain a highly natural landscape. Jeziorak lake shoreline is forested on prevailingly sandy soils with farming land in past separated in the majority by trees and wetland as a buffer. In those times, landscape resources were used for pleasure and rural areas are transformed into a built-up environment. Analysis was undertaken of the interactions between the activity of people attracted by landscape and water and the ecosystem, which provides man with these services and depends on structure, processes and functions. Research questions are related to indispensable conditions for future sustainable use.

\section{METHODS AND MATERIALS}

Our work focuses on landscape pattern characteristics and ecosystem products connected with human demand. Aim is to assess the impact of stresses on the ecosystem in that ecosystem structure and changes in landscape. Landscape is reflected by land use and ecosystem naturalness. It depends on the human activities in littoral. If it is increasing can tread of structure littoral zone changing and might define inflow of pollution what is stated measured. As a response, landscape character and attractiveness, diversification of littoral state and current water state were taken into account. Analysis was conducted according to the conceptual model in which characteristics of elements and flow between by stress as is expressed in Fig. 2 were measured. Changes caused by the group of stressors are estimated in terms of lake attractiveness and quality of ecosystems services with prospects for future interest for people and the economy. Impact in the form of stressors was established according to Fig. 2 in view of wider sustainable interests related to the future use by people [18]. Ways of using the environment examine the interaction of man with the ecosystem. In the analysis, the type of crucial activities that began in the past and which had an important impact on environment, according to the three main stages of ecological development, productive to activities related to economic system, was analysed [19]. From the past, environmental impact involved agriculture, housing and mass recreation. The last impact is due to the change in soil, footpaths on steep embankments built by sandy soils, removing of plants and other giving visual effects were taken into consideration. Interactions were analysed between buildings environment and natural elements, which have a crucial impact on the kind of landscape. Criteria for assessment are a developed ecosystem structure related to semi-natural forest (Fig. 4) and meadows (Fig. 5) and undisturbed littoral zone in the forest and rural area with only a small degree of built-up environment and grouped activities outside the littoral zone. Defined functional, direct effects were attributed to these features, such as erosion, and indirect effects ensued from the effects on the track of flows of matter in the trophy chains, such as the quality of water in the lake.

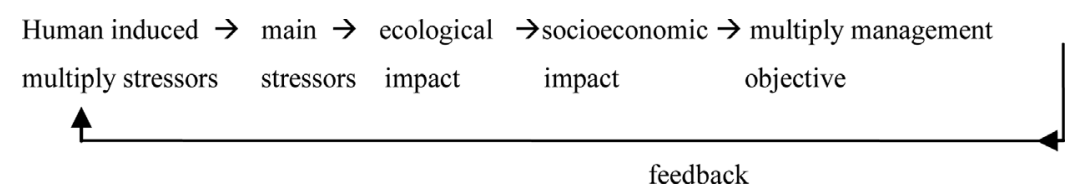

Figure 2: Approach to assess stressors and its impact on sustainability. 
A.J. Czarnecki \& A.L.-Czarnecka, Int. J. of Design \& Nature and Ecodynamics. Vol. 7, No. 3 (2012) 265

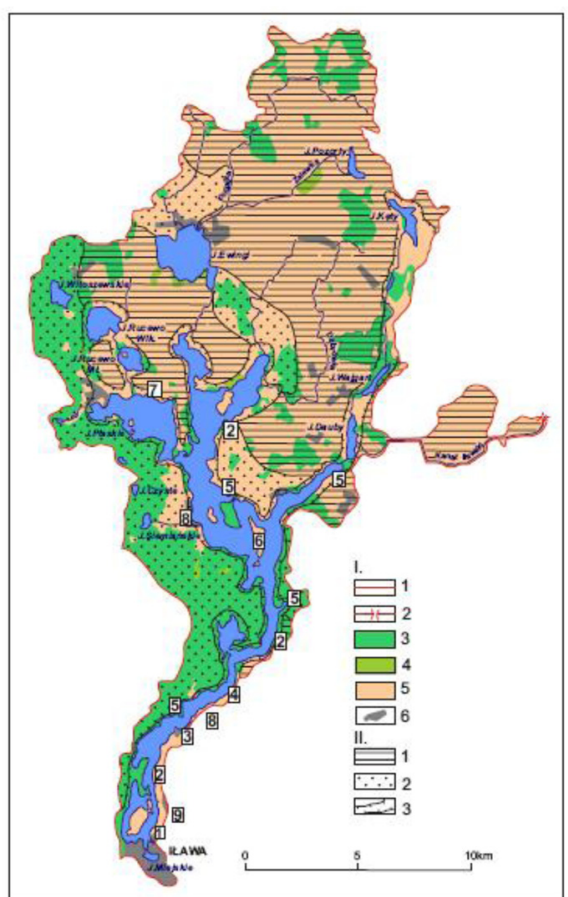

Figure 3: Stable characteristics of catchment area of Jeziorak Lake overall land use and main stressors in shoreline involved by tourist and housing development.

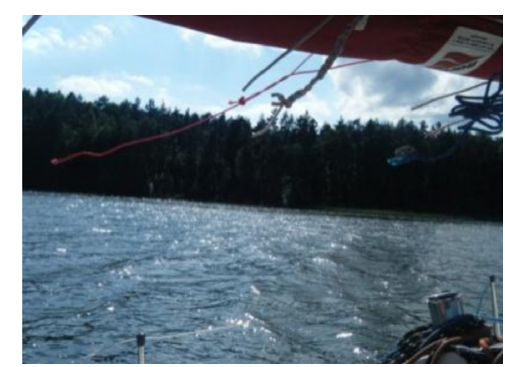

Figure 4: Beauty of lake landscape surrounded by forest.

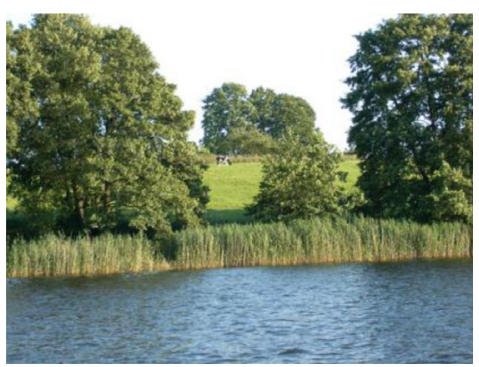

Figure 5: Accepted landscape with view of rural areas. 


\section{RESULTS AND DISCUSSION}

\subsection{Lake landscape visual features and littoral zone at the start of conversions}

It happened in the 1990s together with changes in the political and economic system. The industrial era in Poland came to the end at that time. Human activities, which produced drivers (Table 1) responsible for landscape features and the state of the ecosystem came from farming and urban areas. Farming covered the majority of the catchments area causing harm as water pollution through the surplus of pesticides and nutrients from the North. The rural areas inside was not reinforced by buffer strips except fragments of lake border where narrow strips of trees stand against rural land. Farms did not dispose waste and pesticides in a controlled manner. During that time, two towns Zalewo and Ilawa and the biggest forest workers settlement Siemiany were not equipped with a proper sewage treatment plant. At that time, individual recreation developed locally, in a few places mainly on clearings for mooring (binduga) and some small open boats. Camping facilities for recreation by workers were built by factories' social campaign and were located in forest with sparse trees in Makowo (Fig. 6) and on steep embankments in Siemiany (Fig. 7). Facilities in camps were not sufficient for controlling waste. Functionally rural areas play an important role in directly providing food to visitors. Total stress depends on the inflow of a heavy polluting load of mineral and organic substances. As a result, water quality deteriorated to being unclassed or of third class water purity. Eutrophicated water with low transparency was recognized as the pikeperch type lake. Landscape in view expressed the co-existence between natural and rural elements and maintained the naturalness. Camping sites in the forest were not visible from the lake. The structure of the ecosystem in littoral was not disturbed.

Table 1: Baseline characteristics of natural and socioeconomics values of lake and catchment area.

\begin{tabular}{|c|c|c|c|}
\hline $\begin{array}{l}\text { Landscape a. Shoreline } \\
\% \text { b. density of people }\end{array}$ & Main stressor reason & $\begin{array}{l}\text { Main ecological } \\
\text { impact }\end{array}$ & $\begin{array}{l}\text { Values landscape } \\
\text { socioeconomic }\end{array}$ \\
\hline $\begin{array}{l}\text { Urban a. } 10 \\
\text { b. very dense }\end{array}$ & $\begin{array}{l}\text { Point and non-point } \\
\text { source of waste water } \\
\text { Lack of facilities }\end{array}$ & $\begin{array}{l}\text { Eutrophication } \\
\text { Littoral partly replaced } \\
\text { by technical appliances }\end{array}$ & $\begin{array}{l}\text { Considerable rather } \\
\text { public lowering by } \\
\text { unclear water }\end{array}$ \\
\hline $\begin{array}{l}\text { Forest a. } 10 \\
\text { b. locally dense }\end{array}$ & $\begin{array}{l}\text { Locally non-point source } \\
\text { of waste water and lit- } \\
\text { toral destruction tourists } \\
\text { on camp sites }\end{array}$ & $\begin{array}{l}\text { Contribute to water } \\
\text { eutrophication littoral } \\
\text { locally degraded }\end{array}$ & $\begin{array}{l}\text { Houses fitted public } \\
\text { value but damages in } \\
\text { ecosystem lowering }\end{array}$ \\
\hline $\begin{array}{l}\text { Natural a. } 40 \\
\text { b. low }\end{array}$ & $\begin{array}{l}\text { Local point source } \\
\text { of waste water and } \\
\text { sediments from erosion } \\
\text { involved by treading } \\
\text { on slope Tourists on } \\
\text { bindugas }\end{array}$ & $\begin{array}{l}\text { locally degraded } \\
\text { ecosystem }\end{array}$ & $\begin{array}{l}\text { Camps fitted but public } \\
\text { value ecosystem dam- } \\
\text { ages locally lowering } \\
\text { value }\end{array}$ \\
\hline $\begin{array}{l}\text { Rural a. } 40 \\
\text { b. medium }\end{array}$ & $\begin{array}{l}\text { Waste water and contam- } \\
\text { ination from villages and } \\
\text { crop fields farming No } \\
\text { preservation }\end{array}$ & $\begin{array}{l}\text { Contamination } \\
\text { of water }\end{array}$ & $\begin{array}{l}\text { Rural in harmony public } \\
\text { value with natural lower- } \\
\text { ing by unclear water }\end{array}$ \\
\hline
\end{tabular}




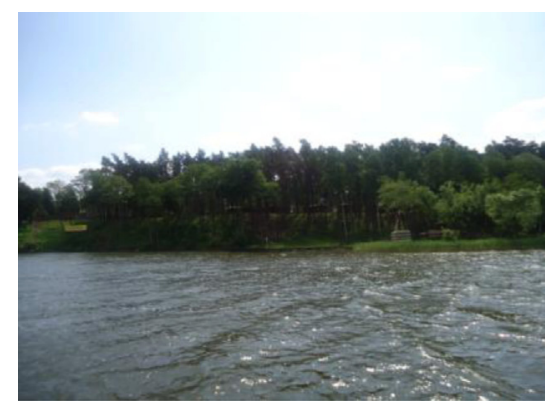

Figure 6: Recreation place in forest landscape near Makowo.

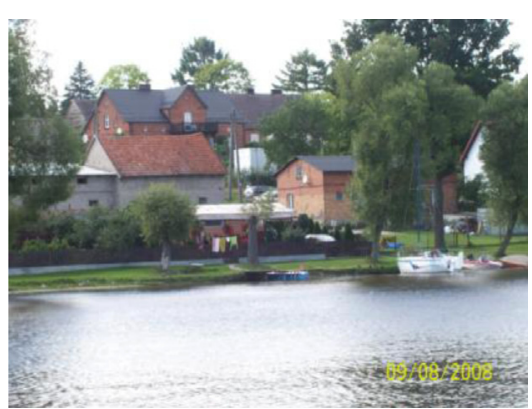

Figure 7: View on houses made by bricks in popular tourist village - Siemiany.

Also, few houses in view are made of bricks that matched with natural elements. Such a landscape is accepted and visitors assess the whole as a unit of very attractive landscape.

\subsection{Changes after the 1990s in towns and the development of tourism}

After accession to the European community, towns and farms began an effective control of the pollution threatening the lake. However, in tourist villages there is still a lack of an adequate sewage system.

In both cities and tourist villages, new stressors on ecosystem occurred. Main reason is enlarging area of building environments. To that landscape changes occurred. Luckily, natural landscape underwent less change. Other are splitting. Urban landscape was divided into suburban (Fig. 8) and then suburban/touristic landscape characterized by two dominating elements. Rural landscapes from Ilawa to Makowo are replaced by tourist type landscapes (Fig. 9). Also forest landscape changed into forest tourist landscape (Fig. 10). In all types of landscape, except natural, is visibly pressing on the ecosystem. In effect, ecosystem services have a decreasing value of regulating functions followed by cultural services. There is a threat for the public interest when the value of landscape is decreases. Deepest changes are on area of around four large tourist centres. In those places, tourist capacities are growing (Fig. 3). Infrastructure, such as camp sites, shops and fast food restaurants are substantially increasing. These sites, together with three to four minor areas, spread on the lake area. Ownership of the tourist recreational camps in the forest have changed and are enlarging their area as well; however, from the lake they are still not clearly visible unless they are located along the lake. In view are numerous places for boat mooring facilities. Only one recreational place situated 

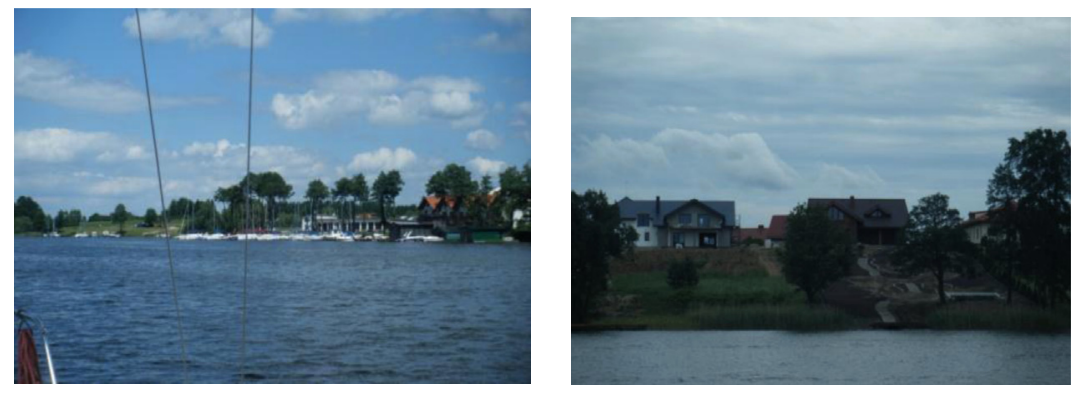

Figures 8, 9: New houses and marina close to Ilava.

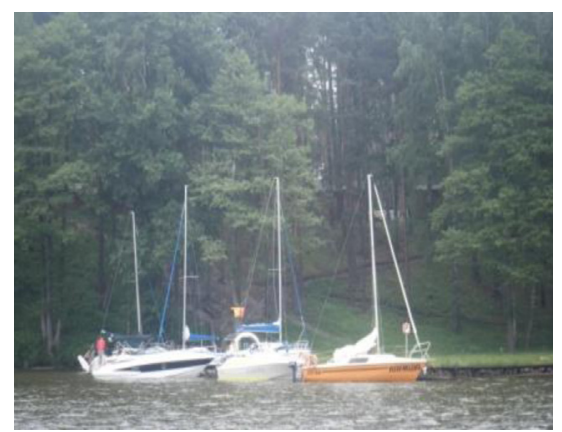

Figure 10: New piers for sailors.

in the forest has access to a small part of the embankment, while occupying sizeable area inside the forest (Figs. 12 and 13). The scale of tourism arranged mainly along the shoreline cause new stress by removing the natural plants communities and replacing the soils and plants with grass matting and used chemicals to protect it (Table 2). This has resulted in a stress to the ecosystem and has added to other threats (Table 3). The main impact spills from the littoral zone. Along the land border, the littoral has deteriorated in many parts where shores are not very steep. Close to camps near Makowo, it is lower because there is a very steep shore. In Siemiany, the escarpments are being partly destroyed by the treading (Fig. 14), while there is a lack of protective strengthening of the escarpment. Some parts of littoral are replaced by beach. North of Ilawa up to Makowo almost all rural land close to the lake were transformed for tourist use. New houses in one row separated from the lake by gardens are built in a wide range of standards. Some are very big and comfortable, others are small cheap ones. Some of them can be used the whole year, while others are cheaper and for seasonal use. Together with the change in the type of the landscape and land cover, the ecosystem lost part of its structure in many places [20]. Large fragments of the littoral are trampled down. In the upper part of the littoral, natural flora and meadow plants are replaced by lawns. It is preceded by earthworks (Fig. 15). Natural soils are often removed too and are replaced by soils rich in humus for the green lawn, which are fertilized with nutrients. Bathing beaches are being made in the littoral, so sand is introduced. In such places, plants in the littoral are removed. We can expect that protective functions of the ecosystem are weakening. Next impact came from sailing boats $(6-10 \mathrm{~m})$ whose number is increasing. Now 600-800 sailing boats are used in season. They are grouped in centres with services in Siemiany, on shores around the islands and in single mooring sites close to the forest (Fig. 11). Very recently, 


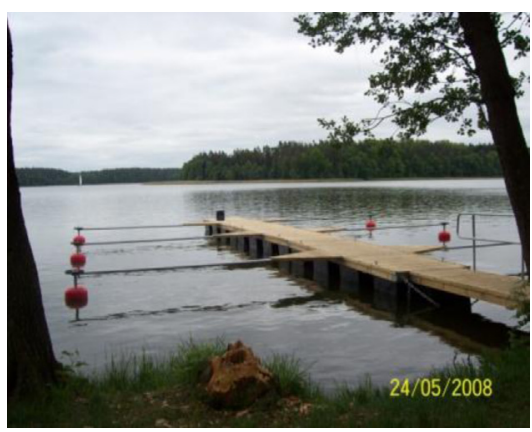

Figure 11: Recreation in forest areas of banks.
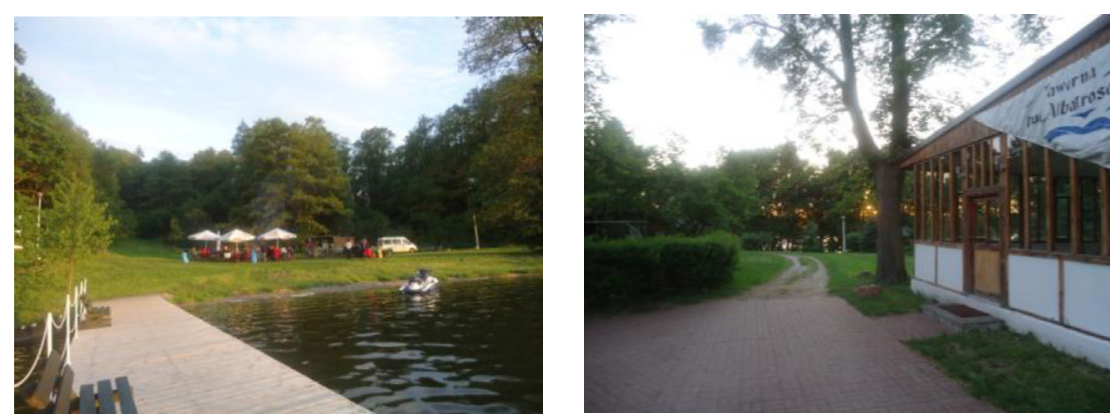

Figures 12, 13: A camp in peaceful forest connected with small creek on lake.

Table 2: Characteristics of natural and socioeconomics values of lake and catchment area due to tourism development.

\begin{tabular}{|c|c|c|c|}
\hline $\begin{array}{l}\text { Landscape } \\
\text { a. Shoreline \% } \\
\text { b. density of people }\end{array}$ & Main stressor change & $\begin{array}{l}\text { Main ecological } \\
\text { impact }\end{array}$ & $\begin{array}{l}\text { Values } \\
\text { Landscape } \\
\text { Socioeconomic }\end{array}$ \\
\hline Urban a. 5 & Controlled waste water Tour- & Less contribution to & Still lowering \\
\hline b. dense & ist work in littoral Change in & eutrophication littoral & Public by unclear \\
\hline $\begin{array}{l}\text { Suburban } \\
\text { a. } 5 \\
\text { b. medium }\end{array}$ & $\begin{array}{l}\text { littoral non-point source of } \\
\text { waste water }\end{array}$ & $\begin{array}{l}\text { replaced } \\
\text { Littoral plants partly } \\
\text { removed }\end{array}$ & $\begin{array}{l}\text { water Houses not fit- } \\
\text { ted Private damages } \\
\text { in ecosystem lowering }\end{array}$ \\
\hline Forest a. 10 & Camp sites and villages & Eutrophication & Camps partly \\
\hline b. Small centres & $\begin{array}{l}\text { Growing slope destruction } \\
\text { by treading, swimming, piers }\end{array}$ & $\begin{array}{l}\text { Littoral locally } \\
\text { degraded }\end{array}$ & $\begin{array}{l}\text { not public fitted } \\
\text { Ecosystem damages }\end{array}$ \\
\hline Big centres & & Water shallowing & Locally lowering value \\
\hline Natural a. 40 & Decreasing impact on littoral & Less stress for & Beautiful \\
\hline b. low & Waste water while bathing & ecosystem & $\begin{array}{l}\text { Public lowering by } \\
\text { unclear water }\end{array}$ \\
\hline $\begin{array}{l}\text { Rural a. } 20 \\
\text { b. medium }\end{array}$ & Decreasing impact from farms & $\begin{array}{l}\text { Less stress for } \\
\text { ecosystem }\end{array}$ & $\begin{array}{l}\text { In harmony } \\
\text { Public with forest }\end{array}$ \\
\hline $\begin{array}{l}\text { Touristic a. } 20 \\
\text { b. Medium }\end{array}$ & $\begin{array}{l}\text { Soil remove change plant cover } \\
\text { use fertilizers and pesticides } \\
\text { remove part of littoral plants }\end{array}$ & $\begin{array}{l}50 \% \text { of littoral plants } \\
\text { removed contam- } \\
\text { ination shallowing }\end{array}$ & $\begin{array}{l}\text { Chaotic bad } \\
\text { Mainly impact on } \\
\text { private ecosystem }\end{array}$ \\
\hline
\end{tabular}



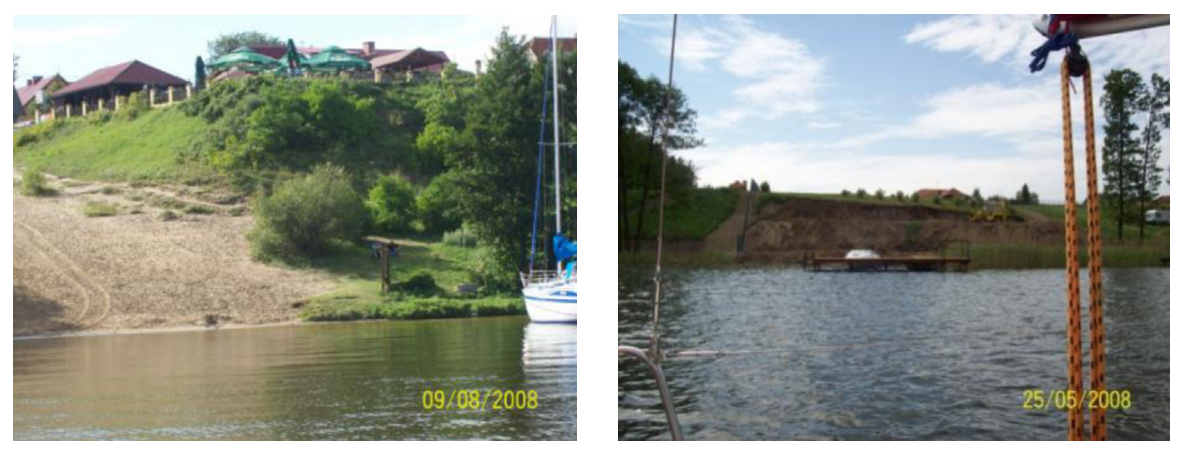

Figures 14, 15: Deep interference in structure rural areas.

on many attractive places close to Ilava and Siemiany marinas with numerous piers were organized (Fig. 11). There are many simple toilets and containers for litter organized close to those marinas, all supported by EU funds. Rather insufficient infrastructure and behaviour of sailors admitted a heavy inflow of waste to the lake water. Together from all sources it can be assessed that the total impact on lakes is still huge. Total inflow of waste is probably the same, though the sources are changed. Moreover, organic and inorganic mass in the form of soil particles and water solution, moving down the slope also pollute the lakes. Damage in the littoral is decreasing its buffer ability, hence facilitating easy spread of matter. As a result, water quality is still low and occasionally in most polluted places around campsites cyanobacteria occur. Landscapes are changed and new views express the deterioration of the littoral and presence of numerous people contribute to noise pollution. It has resulted in lowering aesthetic values of the landscape of Jeziorak Lake in the southern part. The impression on tourists of more sublimed requirements is not good.

\section{RECOMMENDATIONS}

Developing tourism and recreation around Jeziorak Lake is not directed to sustainability. Main reason is caused by strong impact on shoreline by visitors where they spent almost the whole time of stay. Together with settlers they are a huge threat for lake attractiveness and ecosystem functions, while low volume of water in lake make ecosystem very vulnerable. Environmental infrastructure is still not adequate with enlarging capacity for mass tourism. For public use and opportunity for job, these can make a threat to the, nevertheless, interesting landscapes of Jeziorak Lake. There is no use of attractions of Landscape Park, which can enable the visitors to plan many days of staying to participate in different activities inside area. To expand tourism on the whole area might be pressing on the littoral. Next step can be the invert tendency to change landscape from more natural to urban by tree planting and make by them a buffer strip which may lower the impact on the lake's environment. Limiting the number of marinas while maintaining the existing ones in good condition may effectively protect the shoreline and water. Experiences from other countries proved that visitors' activities are dependent on portfolio information about land surrounding water. On researched area, only positive example of controlled impact on ecosystem was seen in a small resort where visitors spent majority of time in comfortable conditions in huts or pensions in calm forest situated above lake. There is one weakness of this place, that is, lack of portfolio of half-day excursions around. So it is suggested that information may be provided which can change the attitude of visitors and vitalize all area of lake catchment. Such policy in many tourist places in Europe has brought expected results. For example, in a small Baltic island Bornholm, tourist resources are comparable in terms 

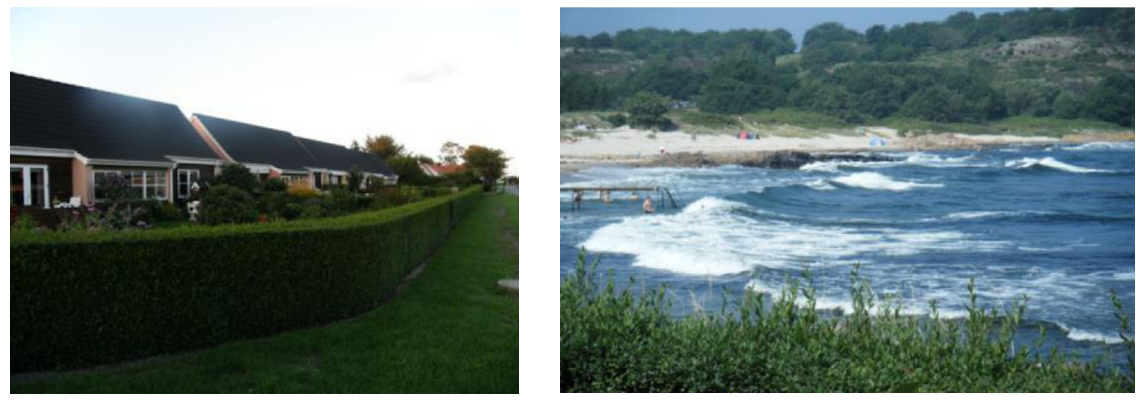

Figures 16, 17: Bornholm inland engaged visitors.

of attractions. The accommodations (Fig.16) are inside. Visitors widespread on all territory never grouped in one place. In summer, they disperse to many different parts of the island with no crowding anywhere including sea shores (Fig. 17).

\section{CONCLUSIONS}

Shallow lakes are susceptible to eutrophication and it is difficult to change the state enabling the development of underwater plants for self-cleaning water. As regards the lakes whose catchment areas are used for farming and attract tourism, they require very careful management. Even if people accept not transparent water, the occurrence of cyanobacteria would be a threat for the ecosystem as well as for users of the water and landscape. The effect of so many users, among whom some have a more or less unacceptable impact on lakes, must be recognized and decreased. Nowadays, it is visible that Ilawa and other places where visitors are substantially grouped have stopped the inflow of waste to the lake. However, it has not resulted in water improvement. At the same time, the growing number of tourists in places where waste is not fully controlled makes a new important source of inflow waste to water. The behaviour of tourists using lake water to wash themselves and kitchen utensils must be changed and places for grouping of sailors ought to be equipped with facilities. Inadequate reinforcement of slopes causes erosion and inflow to the lake of sand and organic matter. Numerous places built for bathing destroy littoral plants that are an element of the ecosystem structure with many important functions for providing clear water. The change in land use causes the inflow of very huge amounts of inorganic and organic matter, while houses are built and lawns made. Landscape visible features reflect that burden together with littoral pressure. A strict regime of limiting the impact on the environment is not imposed which would result in the increase of the total burden, despite efforts to stop the main sources of pressure. This bias arises from the fact that the burden is shared by large groups, inflow of waste are related to numerous number of visitors, and relatively small groups of owners of residents with an impact on the littoral. Our analysis suggests that the following three key ingredients are needed to correct the problems of bias and compromise. Ecosystems are of importance to several different stakeholders; however, while all want clean water, others prefer a good quality landscape and for others biodiversity is most important. Some ways of using the ecosystem services tend to lower the quality of the system for other users; there is often a conflict of interests. The attitude of man to structures responsible for the quality and the usefulness of ecosystem services influences the general attraction and value of the landscape. So above all, lakes cannot be used to get rid of waste water or used for washing or for fishermen who feed fish before catching them. The response to eutrophication and subsequent restoration efforts concerning lakes with such properties can be easily understood from this representation. Starting from a return 
to a pristine state, with a decrease in the nutrient level, if no large perturbations occur, the lake will return to and stay in the clear state. An awareness that it is necessary to re-naturalize should motivate this as should the need to renovate ecosystems to provide man with the appropriate living conditions. In the case of Jeziorak, the phenomenon of tourism described for the development and building phase concerns only about $50 \%$ of the shoreline and has not concerned the area of the drainage area until now. There is a rally time for dispersed visitors and building beyond the lake shore. It would engage other resources, such as the landscape surrounding the lake with access to the lake port and beach. Such development enables the maintenance of the naturalness of the landscape which is considered as the main trademark of tourist attractions of this area. The individual character of land use transformation caused adverse effects in the ecosystem structure and usable services and it bears a threat of invert interest from the part of users with damage for the local economy. A solution might come from talks and a focus on common benefits against private ones.

\section{REFERENCES}

[1] Briassoulis H., Sustainable tourism and the question of the commons. Annals of Tourism Research, 29(4), pp. 065-1085, 2002.

[2] Gretchen, C.D., Management objectives for the protection of ecosystem services. Environmental Science \& Policy, 3, pp. 333-339, 2000. doi: http://dx.doi.org/10.1016/S1462$\underline{9011(00) 00102-7}$

[3] Czarnecki A., Luc M. \& Lewandowska-Czarnecka A., Ecological capacity measurements as useful tools of planning land management in a lake district: Iława Landscape Park case study. Environmental economics and investment assessment, ed. C.A. Brebbia, WIT Press, Wessex Institute of Technology, pp. 295-306, 2006a.

[4] Scheffer, M., Alternative stable states in eutrophic, shallow freshwater systems: A minimal model. Hydrobiol Bull, 23, pp. 73-83, 1989. doi: http://dx.doi.org/10.1007/BF02286429

[5] Scheffer, M., Multiplicity of stable states in freshwater systems. Hydrobiologia, 200/201, pp. 475-486, 1990. doi: http://dx.doi.org/10.1007/BF02530365

[6] Hutchinson, G.E., A Treatise on Limnology. Vol. 3, Limnological Botany. New York: Wiley, 1975.

[7] Chambers, P.A. \& Kalff, J., The influence of sediment composition and irradiance on the growth and morphology of Myriophyllum spicatum. Aquatic Botany, 22, pp. 253-264, 1985. doi: http://dx.doi.org/10.1016/0304-3770(85)90003-8

[8] Vant, W.N., Davies-Colley, R.J., Clayton, J.S. \& Coffey, B.T., Macrophyte depth limits in north island New-Zealand lakes of differing clarity. Hydrobiologia, 137, pp. 55-60, 1986. doi: http:// dx.doi.org/10.1007/BF00004172

[9] Skubinna, J.P., Coon, T.G. \& Batterson, T.R., Increased abundance and depth of submersed macrophytes in response to decreased turbidity in Saginaw Bay, Lake Huron. Journal of Great Lakes Research, 21, pp. 476-488, 1995. doi: http://dx.doi.org/10.1016/S0380-1330(95)71060-7

[10] Schreiter, T., Untersuchungen u ber den Einfluss einen Helodeawucherung auf das Netzplankton des Hirschberger Grossteiches in Bo"hmer in den Jahren 1921 bis 1925 incl V. Praze. Prague. 1928.

[11] Canfield, D.E., Shireman, J.V., Colle, D.E., Haller W.T., Watkins, C.E. \& Maceina, M.J., Prediction of chlorophyll a concentrations in Florida lakes: Importance of aquatic macrophytes. Canadian Journal Fisheries Aquatic Sciences, 41, pp. 497-501, 1984. doi: http://dx.doi.org/10.1139/f84-059

[12] Jeppesen, E., Jensen J.P., Kristensen, P., Sondergaard M., Mortensen, E., Sortkjaer, O. \& Olrik, K., Fish manipulation as a lake restoration tool in shallow, eutrophic, temperate lakes 2: threshold levels, long-term stability and conclusions. Hydrobiologia, 200/201, pp. 219-228, 1990. doi: http://dx.doi.org/10.1007/BF02530341 
[13] Pokorny, J., Kvet, J., Ondok, J.P., Toul, Z. \& Ostry, I., Productionecological analysis of a plant community dominated by Elodea canadensis. Aquatic Botany, 19, pp. 263-292, 1984. doi: http://dx.doi.org/10.1016/0304-3770(84)90044-5

[14] Hein, L., van Koppen, K, de Groot, R.S. \& van Ierland, E.C. Spatial scales, stakeholders and the valuation of ecosystem services. Ecological Economics, 57, pp. 209-228 2006. doi: http:// dx.doi.org/10.1016/j.ecolecon.2005.04.005

[15] Papageorgiou, K. \& Brotherton, I., A management planning framework based on ecological, perceptual and economic carrying capacity: The case study of ikos-Aoos National Park, Greece. Journal of Environmental Management, 56, pp. 271-284, 1999. doi: http://dx.doi. org/10.1006/jema.1999.0285

[16] Tress, B. \& Tress, G., Capitalising on multiplicity: a transdisciplinary systems approach to landscape research. Landscape and Urban Planning, 57, pp. 143-157, 2001. doi: http://dx.doi. org/10.1016/S0169-2046(01)00200-6

[17] Wang, H., A systematic approach to natural recreational resources management. Socio-Economic Planning Science, 30(1), pp. 39-49, 1996. doi: http://dx.doi.org/10.1016/0038-0121(96)00001-8

[18] Mihalic, T., Environmental management of a tourist destination. A factor of tourism competitiveness. Tourism Management, 21, pp. 65-78, 2000.

[19] Gómez-Sal, A., Belmontes, J.A. \& Nicolau, J.M., Assessing landscape values: a proposal for a multidimensional conceptual model. Ecological Modelling, 168, pp. 319-341, 2003. doi: http://dx.doi.org/10.1016/S0304-3800(03)00144-3

[20] Czarnecki, A., Luc, M., Lewandowska-Czarnecka, A., West-east inland waterway in Poland in a perspective of European tourism and interregional economy. Journal of Agricultural, Food, and Environmental Sciences, 1, pp. 1-8, 2006a.

[21] Lackey, R.T., Seven pillars of ecosystem management. Landscape and Urban Planning, 40, pp. 21-30, 1998. doi: http://dx.doi.org/10.1016/S0169-2046(97)00095-9 